\title{
A DEMANDA DO SANTO GRAAL: RETÓRICA E PODER NO MILÊNIO
}

\section{The Quest of the Holy Grail: Rhetoric and Power in the millennium}

\author{
Prof. Dr. Marcus Baccega \\ Docente da Graduação e Pós-Graduação da Universidade Federal do Maranhão (UFMA) \\ Departamento de História \\ (BRATHAIR) \\ ORCID: https://orcid.org/0000-0003-2195-5028
}

E-mail: marcusbaccega@uol.com.br

Recebido em: 30/05/2020

Aprovado em: 04/07/2020

\begin{abstract}
Resumo: A finalidade deste breve ensaio é propor um exercício de História Total sobre o Tempo do Milênio a partir da análise retórica e política de um traço de mentalidade que se constitui em verdadeira metonímia da época. Referimo-nos aqui ao mitema do Santo Graal, inescapavelmente atuante nas mais diversas camadas do imaginário centro-medieval, considerando-se o último um sistema semiológico comunicante de um discurso disciplinar. Neste sentido, o Santo Graal apresenta-se como metáfora da Graça e, por conseguinte, do próprio Deus cristão, ao mesmo tempo em que é um traço de mentalidade das formações sociais europeias centro-medievais. Nosso intuito é analisar o regime discursivo normativo e disciplinar presente em A Demanda do Santo Graal a respeito da Ordem da Cavalaria, suscitando a ideia de que os heróis e anti-heróis dessa trama artúrico-graalesca correspondem a modelos de virtudes e vícios. Consagra-se, portanto, a inserção do entrecho romanesco no gênero retórico-poético epidítico.

Palavras-chave: Santo Graal; Retórica; Totalidade Histórica.
\end{abstract}

Abstract: The purpose of this brief essay is to propose an exercise of Total History about the Millennium by leading off from the rhetorical and political analysis of a trace of mentality which constitutes a true metonymy of the period. We here refer to the mytheme of the Holy Grail, inescapably acting out in the manifold layers of centralmedieval imaginary, the latter being conceived as a semiological system that communicates a disciplinary speech. In this sense, the Holy Grail presents itself as a metaphor of Grace, thus, of the Christian God Himself, whilst it is also a mental trace pertaining to the European social formations of Central Middle Ages. Our aim is to construe the discoursive regime of normativeness and discipline that is present in The Quest of the Holy Grail with respect to the Order of Chivalry, thus stiring up the idea that heroes and anti-heroes of this Arthurian plot correspond to models of virtue and vices. The insertion of the romanesque woof into the rhetorical-poetic epidictic genre is consacrated.

Keywords: Holy Grail; Rhetorics; Historical Totality. 


\section{INTRODUÇÃO: O Graal, Mitologia, Exegese.}

Em Verdade e Método (Wahrheit und Methode, 1961), o filósofo alemão de linhagem fenomenológica Hans Georg-Gadamer (1900-2002) caracteriza a experiência intelectual do Ocidente como uma passagem, por vezes intermitente e incompleta, entre a ordenação do mundo pelo mythos ( $\mu$ v́$\theta o \varsigma$ ) e a nova ordenação racional do cosmo pelo

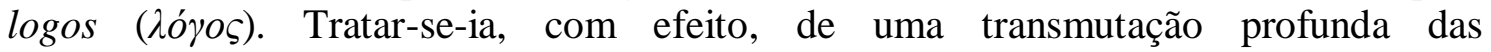
representações de mundo, que abandonariam o regime da mitologia para fincar raízes na filosofia, um saber racional-especulativo, governado por um princípio zetético (oposto ao dogmático).

De um ponto de vista histórico-sociológico, coube a Max Weber (1864-1920) desnudar esta formação do Ocidente moderno capitalista a partir do conceito-chave de desencantamento do mundo (Entzauberung der Welt), expresso no clássico Economia e Sociedade (Wirtschaft und Gesellschaft,1919) e nas duas edições de A Ética Protestante e o "Espírito do Capitalismo" (Die protestantische Ethik und der "Geist" des Kapitalismus, 1905/1919). Em sua ciência social compreensiva, Weber interpreta que a Modernidade teria implicado a progressiva desmagificação do real. Por sua vez, seria o filósofo contemporâneo Jürgen Habermas (1929) a elucidar que o processo histórico de constituição da Modernidade se deu sob o signo da secularização. Não se trata, em momento algum, de uma extinção do sagrado ou falência total das religiões e da mística, mas sim sua circunscrição a uma esfera de valor regida por uma lógica própria, distinta da política, do direito, da erótica, da ciência e da própria ética.

De certa forma, o mito artúrico-graalesco percorre este tenso itinerário - sempre incompleto, insistimos - entre mythos e logos. Com efeito, os mitemas clássicos destas narrativas em torno do Rei Arthur, dos Cavaleiros da Távola Redonda e da Demanda do Santo Graal afastam-se de uma convenção retórica de veridicidade, própria às epopeias, canções de gesta e romans. Cessam, portanto, gradativamente, de produzir, com seus enredos e tramas, um efeito de verdade nas práticas e representações sociais a partir da escrita e publicação da primeira parte de El ingenioso hidalgo Don Quijote de la Mancha, o Dom Quixote, em 1605, por Miguel de Cervantes (1547-1616).

Como nos interpela Michel Foucault (1926-1984), em sua polêmica e antissistêmica obra As palavras e as coisas (Les mots et les choses, 1966), o personagem Dom Quixote é pura linguagem, pura analogia de si mesmo, pura autorreferencialidade (FOUCAULT, 1966: pp. 60-64). Uma facécia deliciosamente crítica e sátira à instituição da cavalaria andante medieval e sua condição de simulacro anacrônico nos primórdios do século XVII (ZUMTHOR, 1987: pp. 301-304) está plenamente encarnada em Dom Quixote.

Por conseguinte, o romance de Cervantes significa a instância em que os romans e novelas de cavalaria veem-se confrontados com sua alteridade ficcional, uma antinovela de cavalaria que, em alguma medida, condena as novelas medievais a uma autofagia enquanto discursos de verdade. De uma convenção retórica de veridicidade, passam ao campo de uma convenção retórica de ficcionalidade (vale dizer, de transcriação artística). Signo da irrupção da Primeira Modernidade (séculos XVIXVIII), não é por acaso que Cervantes é coetâneo de William Shakespeare (1564-1616) 
e sua dramaturgia fictícia e de Luís Vaz de Camões (c.1524-1580), sua épica alegóricoficta e sua poesia, ou quase coevo da pintura barroca de Diego Velásquez (1599-1660).

No entanto, como suspeitava Walter Benjamin (1892-1940), não apenas na clássica A Obra de Arte na era de sua reprodutibilidade técnica (Das Kunstwerk im Zeitalter seiner Reproduzierbarkeit, 1913), mas também no ensaio Capitalismo como Religião (Kapitalismus als Religion, 1921), o desencantamento do mundo exibe, ele próprio, um regime nova de encantamento. Trata-se do fetiche (termo advindo do português feitiço), pelo qual a aura singular das obras de arte cede espaço para o sexappeal do inorgânico, a fantasmagoria do Capital em sua forma mercadoria. Não somente o sagrado de nossos dias foi colonizado, e mesmo nossos genomas tornados venais, como as obras singulares - de retórica ou literárias - encontram-se vulgarizadas sob tal fetiche.

É neste lastro que se revela a indústria cultural capitalista (Theodor Adorno e Max Horkheimer) como poderoso locus social e simbólico de reprodução do Capital em escala ampliada, no circuito suicida de seu Dasein inanimado (BACCEGA, 2008: p. 45). Em seu seio, também a Matéria da Bretanha - que de mito passou a lenda com a constituição de um vazio opaco de uma linguagem autorreferente ao infinito, que é a ficcionalidade literária (FOUCAULT, 1964: pp. 04-06) - é convertida em um obscuro objeto de desejo capturado pelo Capital. Disto dão prova os inúmeros produtos culturais, de romanescos a fílmicos, passando por novas espiritualidades neopagãs, de nosso tempo. ${ }^{1}$

Como estudiosos deste campo fértil de narrativas artúrico-graalescas há pouco mais de uma década, propomo-nos aqui a seguinte questão-problema: a partir de uma leitura retórica e historiográfica, secundada pela análise linguístico-literária, que repense a circulação cultural da Matéria da Bretanha na Idade Média Central (séculos XI a XIII), como libertá-la do fetiche do Capital de nosso presente? Sob qual regime de sentido isto poderia ser efetuado?

\section{RETÓRICA E HISTÓRIA: uma nova episteme para a História da Cultura.}

Após o giro linguístico (linguistic turn) dos anos 1980, a década de 1990 traz um novo solo epistemológico para as Ciências Humanas, uma direção de estudos e pesquisas que considera as relações e tensões de poder, as disputas prático-discursivas (práxis ou perspectiva teórico-prática) nas diversas dimensões e escalas políticas. Tratase do giro retórico (rhetoric turn), que busca resgatar as convenções retóricodiscursivas como locus histórico-social de constituição de verdades partilhadas por determinada sociedade, espaço-temporalmente localizada. Por certo, o giro retórico apresenta aos historiadores um olhar privilegiado sobre as disputas de enunciados e préverdades que competem entre si por hegemonia de sentido e capacidade de persuasão social ampliada.

Em outra oportunidade, afirmamos que as pesquisas desenvolvidas nas esferas da Filosofia da Linguagem, da Filosofia Analítica, da Análise do Discurso e da Lógica 
contemporâneas, com o suporte dos trabalhos de Teoria Literária, procuram evidenciar a necessidade de uma nova arquitetura analítica para a compreensão do campo essencialmente histórico - da comunicação. Essa ressignificação do campo da comunicação se dá, justamente, pelo enfoque da Retórica (ECO, 2007: pp.07-09). Antologia Filosófica, a sintaxe é o nível semiótico em que os signos se articulam a outros signos, estruturando um primeiro nível da gramática do discurso, podendo engendrar paradigmas ou sintagmas. A semântica é, por excelência, a dimensão dos sentidos, ou seja, aquela em que os signos articulam-se a seus significados. Por fim, a pragmática, esfera de relação entre os signos (representamina) e seus usuários linguístico-comunicacionais históricos (interpretantes), também foi designada por Pierce como Retórica Pura (PIERCE, 1972: pp. 92-97).

Insistimos, a este respeito, que:

Como o pensador estadunidense nos sugere, a dimensão retórica/pragmática do discurso, do ato de fala enquanto situação histórica complexa e concreta, é a chave para a compreensão de sua gramática total. Tal é a condição de possibilidade para uma análise sistêmica que não renuncie à totalidade, não desmembre os campos semiológicos conjugados da sintaxe, semântica e pragmática. Neste sentido, qualificar a Pragmática como locus, por excelência, da Retórica, incita a reestrutura desta gramática sob um sintagma cujo núcleo de sentido seja a ação comunicativa concreta, o ato de fala enquanto discurso historicamente regrado e determinado, a relação signo-usuário/intérprete. Rigorosamente, ademais, sequer haveria possibilidade de analisar as dimensões sintática e semântica sem a compreensão da historicidade de uma rede discursiva, haja vista que os sentidos são construídos e modalizados pelos falantes na concretude do ato de fala. Assim, a sintaxe e a semântica são construídas a partir da pragmática comunicacional. O discurso, como jogo lógico entre interlocutores, não é mero instrumento de expressão de conteúdos prévios, mas - muito mais que isso - uma instância de instauração histórica de significados (BACCEGA, 2017: pp.348-349).

As virtualidades heurísticas e interpretativas do giro retórico, que acena para uma possibilidade de compreensão sistêmica dos conflitos e conciliações de uma formação social específica, despertou a sensível inteligência de Carlo Ginzburg para o campo da Retórica. Em sua coletânea Relações de Força: História, Retórica, Prova (Rapporti di forza: Storia, retorica, prova, 2000), resgatando as concepções de Aristóteles sobre Arte Poética e Arte Retórica, o historiador judeu-italiano percebe que a mesma também pode propiciar um método de demonstração racional das hipóteses historiográficas. Em outras palavras, o que Ginzburg percebe - a nosso ver, corretamente - é o potencial teórico-prático da Retórica como método que reafirma o estatuto epistemológico da História, evitando que se recaia nas diversas modalidades de cantos da sereia pósmodernos.

Aristóteles define a Retórica como a arte de produzir e apresentar provas em um debate ou deliberação, bem como perante um magistrado, em um processo. Afastando as paixões do campo da Retórica, Aristóteles preconiza que o orador deve se limitar às provas, não procurando perverter o ânimo do julgador com incitação às paixões. "Tal procedimento equivaleria a falsear a regra que se pretende utilizar" (Arte Ret. I, 1,5).

Portanto, "é igualmente evidente que, em um debate, devemos limitar-nos a demonstrar que o fato existe ou não existe, sucedeu ou não sucedeu" (Arte Ret. I, 1, 6). 
A Retórica se estrutura, no fundo, em torno dos entinemas, formas de silogismo em que se efetua uma demonstração da veridicidade e da correção das afirmações de um orador. Em Aristóteles, o entinema apresenta uma distinção fundamental com relação ao silogismo apodíctico, pois nesse último as duas premissas, maior e menor, estão patentes e a conclusão é uma decorrência necessária da adequação entre ambas. No entinema, uma das premissas é apenas pressuposta, não enunciada textualmente, ou pode mesmo não existir, precisando advir de uma invenção discursiva do orador. Neste caso, a conclusão não é necessária, mas apenas possível e, se defendida de modo persuasivo pelo orador, pode ser provável.

Aristóteles sacramenta a função e a utilidade da Retórica por meio da afirmação de que o verdadeiro e o justo, objetos desta Arte, são naturalmente preferíveis em relação a seus contrários. Assim, muitas vezes o esforço de persuasão racional do auditório se dá em nome das insuficiências do discurso comum, distinto daquele da Lógica Formal, em apresentar um grau peremptório de certeza. A verdade finda por triunfar por meio da argumentação entinemática. Essa última precisa ser constituída de modo eficaz e mostrar-se apta para debelar a argumentação antagônica, aquela que não guarda compromisso com o verdadeiro e o justo. Aristóteles ainda explicita:

(...) Ora, nenhuma das outras artes conclui os contrários por meio do silogismo, a não ser a Dialética e a Retórica, porque uma e outra têm por objeto os contrários. Todavia, as matérias que lhes dizem respeito não apresentam o mesmo valor, porque o que é verdadeiro e naturalmente superior presta-se melhor ao silogismo e é mais fácil de persuadir, absolutamente falando. Além disso, seria absurdo que a incapacidade de se servir de suas forças físicas em defesa própria gerasse a vergonha e que a incapacidade de se utilizar de suas possibilidades oratórias não a gerasse, uma vez que essas últimas tocam mais de perto ao homem do que o uso de seus membros (Arte Ret. I, I, III, 12).

Procurando sintetizar seu conceito de Retórica, Aristóteles assinala que sua função não é propriamente persuadir, e sim discernir os meios de persuasão a propósito de cada tipo de questão tratada. Assim como a Dialética tem por função distinguir o silogismo verdadeiro do aparente, a Retórica se ocupa de discernir quais espécies de argumentos são verdadeiramente capazes de persuadir, rejeitando os que não o forem.

Tal como há três partes em todo o discurso, ou seja, o orador, o destinatário e o tema da fala, a Retórica clássica conhece três gêneros fundamentais: o deliberativo, o judiciário e o demonstrativo (dito também epidítico). Devemos agora ressaltar que o último comporta duas partes, o elogio e a censura. Cada qual dos gêneros relaciona-se a um momento. $\mathrm{O}$ deliberativo volta-se para o futuro, pois aconselha ou desaconselha uma decisão - política - que produzirá efeitos posteriores. Já o judiciário, dirigindo-se à persuasão do juiz e esperando dele obter um veredicto acerca de um fato pretérito, um 
crime ou outra questão controversa de direito, inclina-se para o passado. $\mathrm{O}$ gênero retórico que, por excelência, tem o presente como horizonte de perfecção é o epidítico. Isso, para Aristóteles, na medida em que as ações retóricas de louvar ou censurar precisam estar fundamentadas na condição atual dos negócios.

Da mesma forma, cada um dos gêneros apresenta uma finalidade própria. No caso do deliberativo, trata-se do útil e do prejudicial, já que algo é apresentado como vantajoso quando se procura convencer o outro a adotá-lo, ou como funesto, na hipótese oposta. Para o gênero judiciário, Aristóteles concebe que se trate do justo ou do injusto, como no caso epidítico o escopo é moldar as ações dos homens, a partir do emprego de exemplos de conduta tidos como virtuosos ou demeritórios. Há um conjunto de pressupostos comuns para os três gêneros retóricos clássicos, referentes à verossimilhança, à fronteira entre aquilo que pode efetivamente acontecer e o que jamais pode se suceder, portanto, entre o verdadeiro e o falso, o possível e o impossível (Arte Ret. I, III, II, 8). Para o discurso epidítico, revela-se fundamental também a definição da virtude e do vício, do que é moralmente belo ou horrível. ${ }^{2}$

Carlo Ginzburg observa uma convergência teórico-prática entre o gênero retórico clássico judiciário e a tarefa do historiador, que se vê às voltas com a reconstituição de eventos, sejam pretéritos ou contemporâneos a ele, a partir de indícios, vestígios indiretos. Seja no tempo presente ou em outras temporalidades - que continuam se interpenetrando no presente - sempre serão fragmentos à primeira vista incongruentes daquilo que é, em sua processualidade, uma totalidade histórica (GINZBURG, 2003: 144-146). Daí a proposta metodológica de um paradigma indiciário.

Não nos parece árduo perceber, nesta afinidade eletiva entre o gênero retórico judiciário e o raciocínio, por vezes entinemático (ao qual Jacques Le Goff atribui o nome de "imaginação"), principalmente se pensarmos no Direito Processual Penal. Há grande contribuição teórica, a tal respeito, por parte penalista René Garraud (18491930), em seu Compêndio de Direito Criminal (Précis de Droit Criminel, 1903), bem como de seu filho e sucessor na Faculdade de Direito de Paris, Pierre Garraud (18881965) em seu tratado A prova por indícios no processo penal (La preuve par índices dans le procès pénal, 1913) (ASSIS MOURA, 2009: p. 67). Na doutrina processualista brasileira, o jurista João Mendes Júnior (1856-1923), traz essas contribuições em seu Curso de Direito Criminal Brasileiro (1911), ensinando que toda a investigação, instrução criminal ou julgamento - funções análogas àquelas atuados no ofício de historiador - devem-se formular e enunciar as Sete Questões do Injusto: Quid (o quê); Quis (quem); Cur/Quare (por quê); Quando (quando); Ubi (onde), Quomodo (como); Ad quem (para quem)?

As Sete Questões do Injusto permitem que se reconstitua o contexto em que se deram os eventos narrados (forma gramatical da História) ou problematizados (cerne semiológico da História) pelos historiadores, abrindo-lhes as vias de compreensão da totalidade processual de que sua investigação se ocupa. Como leciona Carlo Ginzburg, a análise retórica nos propicia condições de atuar a lógica dialética no estudo da História, vale dizer, iniciar pelo singular (particular), inseri-lo na sintaxe do universal (geral) e, em movimento oposto, retornar ao particular com capacidade de compreender sua efetiva unicidade. O particular só pode ser efetivamente entendido nesta operação de sentido em que o historiador, como o juiz, o promotor de justiça e o advogado, faz aflorar o que Hegel denomina universal concreto (GINZBURG, 2008: pp. 59-62). 
Qual, então, o conteúdo retórico do mito artúrico-graalesco em sua tessitura histórica concreta?

\section{A RETÓRICA DO SANTO GRAAL.}

Como pudemos ler na Arte Retórica de Aristóteles, compilada em torno de 350 a.C., a argumentação presente ao gênero demonstrativo ou epidítico pode, muitas vezes,

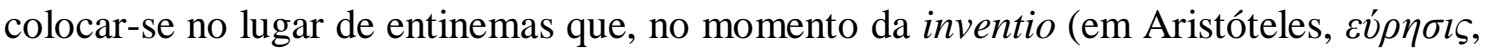

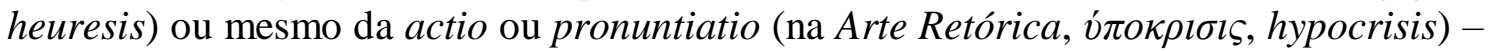
instantes, respectivamente, da adução e da enunciação final dos argumentos - não conseguem ser adequadamente formulados.

Nas Artes Poetriae centro-medievais, tratados de retórica e gramática para uso no Trivium, a inventio ${ }^{3}$ - subdividida em exordium, narratio, partitio, confirmatio, reprehensio e peroratio - bem como nas Artes Dictaminis, constitutivas de uma tradição retórica medieval que retoma a epistolografia clássica e tardo-antiga - é o locus do exercício intelectual da imaginatio e da imitatio. Impende enfatizar o que ensina o retórico medieval anglo-normando, professor na Universidade de Paris, John of Garland (1195-1272), em sua Parisiana Poetria (c. 1240): a inventio retórica consiste em atingir o verdadeiro conhecimento de um ente desconhecido por meio de um comando da razão, que, para tanto, se vale de imagines. Neste sentido, a inventio - de in-venio, ire (encontrar, "ir adentro") - é uma atuação do logos humano que, a partir da similitudo entre res (coisas) e verba (palavras) que identifica o pensamento analógico medieval (FOUCAULT, 1966: pp. 60-64), para atingir o Logos eterno de Deus, as realidades transcendentes últimas.

Hilário Franco Júnior, salientando a condição não moderna da forma medieval de pensar o cosmo, ou seja, a apreensão do mundo enquanto uma intrincada rede de signos analógicos, que faz do real uma correspondência eterna entre significantes e significados (FRANCO JR, 2003: pp. 80-82), acena para uma perspectiva que será chancelada por Márcia Mongelli e Yara Frateschi. Com efeito a inventio, como exercício de imaginatio, instaura uma observação do real físico, que deve permitir ao rhetor (o retórico) descobrir as leis (relações geométricas e musicais transcendentais), cifradas nos números de uma constelação pitagórica. Identificadas e decodificadas tais relações matemáticas, a inventio ainda abrange o manuseio dos temas e argumentos que possa transformar o real visível em uma amostra do real metafísico (MONGELLI; FRATESCHI, 2003: pp. 37-39).

Se pudermos, neste lastro, considerar os romans centro e tardo-medievais como materializações do gênero epidítico, sua finalidade retórico-pedagógica se dá em dois planos: a persuasão de um auditório restrito primeiro - a nobreza feudal de senhores e cavaleiros - e, ao mesmo tempo e de forma ampliada, de um auditório amplo - a Cristandade Latina como um todo, ou Igreja enquanto instituição total - apontando para um projeto de poder universal.

Com efeito, por meio daquilo que, na Tópica aristotélica, se consagrou como ethos retórico, as narrativas artúrico-graalescas instituem o bonus vir christianus, na 
figura do cavaleiro perfeito e imaculado Galaad, verdadeiro Alter Christus escatológico, identificável ao Profeta Elias. Perceval, nas primeiras narrativas arturianas, ainda figura como o cavaleiro virtuoso destinado a solucionar o mistério do Graal na corte de seu avô, o Rei Pescador, notadamente em Perceval ou le conte dou Graal (c. 1189), de Chrétien de Troyes. No Ciclo da Vulgata (c. 1220) e no Ciclo da Post-Vulgata (c.12301235) das estoires do Graal, Perceval será a imago - modo de decifração racional dos significabilia cristãos com o auxílio de imagens, ou seja, formas que imitem harmônica e matematicamente o modelo original transcendente - do cavaleiro virtuoso terreno, imago de Galaad, o cavaleiro do Milênio crístico (Livro do Apocalipse, Cap. 20). Nas três versões ducentistas de A Demanda do Santo Graal, quais sejam, a bretã de c.1235, a portuguesa de 1248 e a alemã de c. 1290 (compilada, em cerca de 1576, no códice Prosa-Lancelot), Perceval é digno do Graal, mas se se faz um só com Ele - que é significante eucarístico de Deus - como ocorrerá com a sacramentalização da Graça em Galaad. Não por outra razão, o ethos retórico encontra seu lugar discursivo privilegiado no exordium, primeira parte da inventio.

Do mesmo modo, o logos retórico, cuja sede é a narratio, que as Artes Poetriae e as Artes Dictaminis centro-medievais fazem equivaler a uma argumentatio, é a instância em que a voz da auctoritas se faz ressoar e expressa o conteúdo moralpedagógico e persuasivo do escrito. Não parece difícil perceber que todo o entrecho das narrativas sobre o Rei Arthur e o Santo Graal é um grande solo retórico em que as razões últimas dos comportamentos sociais desejados são apresentadas e, à maneira de entinemas, corroboradas pelos "exempla" cavaleirescos. No caso do mito artúricograalesco, está sob enfoque qual o bonus vir christianus adequado ao Tempo do Milênio, aquele que, à imagem de um isapostolus, deve secundar a aventura sacramental-cavaleiresca de Galaad. Pensamos não ser despropositado, desta forma, suscitar que a virgindade, pureza e imaculada de Perceval não são suficientes para sacramentar o Alter Christus. É necessária a comunhão radical com o Graal-Deus - ou seja, fazer-se um com Deus, fazer-se Deus dentro da Trindade-Graal, algo apenas reservado a Galaad.

Importa agora refletirmos sobre o pathos retórico, vale afirmar, os argumentos aportados para a detração e negativação das paixões desordenadas. Se Tísias e Córax centraram o enfoque da Retórica, no século V a.C., no $\log o s$ da $\operatorname{argumentação,~à~}$ maneira dos juízos de probabilidade dos sofistas, Aristóteles, na Arte Retórica, percebe a necessidade de adicionar a atenção discursiva sobre o ethos e, em não menor medida, o pathos. Se o ethos constrói a figura do bonus vir, compete ao pathos tecer a figura anti-heroica do pecador, do danado, do condenado.

Nos enredos arturianos e graalescos, está presente uma apropriação cristã da ideia de enaltecer o herói, o cavaleiro ideal, portador do metron ( $\mu \dot{\varepsilon} \tau \rho o v)$, a justa medida, a aura mediocritas ou media res, o pathos $(\pi \alpha$ á $\theta \varsigma$ ) revela a figura proscrita, indigna da virtude e, por conseguinte, da comunhão eucarística com o Santo Graal. Trata-se do cavaleiro Lancelot, culpado por felonia, a grande noxia social contra os contratos feudovassálicos, por trair seu rei e senhor, Arthur, ainda mais por manter amores perjuros com a Rainha Guinevere. Tal relação clandestina o torna, simbolicamente, além de adúltero e desleal, um incestuoso, uma vez que a rainha figura como mãe simbólica de seus súditos, uma antiga tradição céltica (FRANCO JR, 1996: pp. 142-143). 
Por isso mesmo é que o pathos encontra abrigo na peroratio ou conclusio, parte derradeira da inventio, em que se expressa a condenação final do antiexemplo, atuandose um duplo artifício retórico. Em primeiro lugar, a antítese entre Galaad ou o bonus vir christianus (sergente de Jesus Cristo) e seu pai Lancelot, o cavaleiro que incide em todos os desvios do amor cortês e da paixão cavaleiresca "selvagem", de tipo tristânico (DUBY, 2001: pp. 60-63). Aqui estamos diante da antítese, o contraponto da metáfora utilizada no exordium pela estratégia discursiva do ethos. Em segundo lugar, veicula-se o tropo da epanortose, ou seja, colocar o correto ou virtuoso para substituir o vicioso. Tal se faz quando, na peroratio, Galaad é sagrado como cavaleiro santo e imaculado e se coloca, de pleno direito, no posto antes ocupado pelo condestável Lancelot, seu pai: $o$ melhor cavaleiro do mundo.

Na Demanda do Santo Graal portuguesa, inclusive, Lancelot e a Rainha Guinevere, ao final da narrativa, serão condenados ao fogo eterno do Inferno, cena que, nas Demandas do Santo Graal alemã e bretã, permanece em suspensão, em elipse. O efeito retórico integral da combinação entre metáfora (Galaad como Alter Christus e o Santo Graal como Deus), antítese (Lancelot e Galaad) e a epanortose (Galaad assume o antigo predicado de Lancelot como melhor cavaleiro do mundo) é a amplificatio. Desta forma se consegue realizar a persuasão global, não apenas do auditório restrito da nobreza feudal e sua autorrepresentação como bellatores, mas - e talvez principalmente - mas a catequese em escala ampliada de toda a formação social em foco, ou as várias sociedades do Ocidente cristão feudal.

Mas, afinal, o que está em jogo na disputatio retórica artúrico-graalesca? Como já pudemos discorrer em diversas intervenções e escritos, pensamos haver uma chave de interpretação da tensão retórica que permeia as narrativas arturianas, intensificando-se à medida que se acentua a clericalização do mito arturiano. Tal senha reside no tratado $D e$ laude novae militiae (c. 1130), um panegírico à Ordem dos Pobres Cavaleiros de Cristo e do Templo de Salomão (os Cavaleiros Templários), ordem de monges-guerreiros fundada em 1118, em torno do nobre Hugo de Payens (1070-1136), vassalo dos condes da Champanha, seu primo André de Montbard (c.1097-1156) e Godefroy de Saint-Omer (datação incerta), vassalos dos condes de Flandres e Foulques d'Angers (Foulques IV d'Anjou, 1092-1143), que viria a suceder Balduíno II, em 1131, como Rei de Jerusalém.

O tratado foi redigido pelo sobrinho de André de Montbard, o cisterciense São Bernardo de Claraval (c.1090-1153), preeminente ideólogo orgânico (Antonio Gramsci) da Segunda Cruzada (1147-1149) e do pontificado de Eugênio III (1145-1153), fundador da Abadia de Claraval em 1115, da qual foi prior, e verdadeiro configurador ideológico da Ordem do Templo. A Ordem seria chancelada em 1128, no Concílio de Troyes, pelo Papa Honório II (1124-1130), ocasião em que adotam a Regra de São Bento. Em 1145, o Papa Eugênio III lhes outorga o privilégio de ostentar a cruz vermelha sobre fundo branco como brasão da Ordem. Aqui já importa destacar que o cavaleiro Galaad, tal como se apresenta, pela primeira vez, conduzido por um ancião, "monge branco", perante a Távola Redonda, veste armadura branca e escudo branco com a cruz vermelha. Trata-se de um episódio comum às três variantes ducentistas de $A$ Demanda do Santo Graal.

Já pudemos insistir, em outro texto, que o Abade de Claraval arquiteta a formação de um ethos novo para a pequena nobreza de cavaleiros, consistindo, em síntese, na renúncia radical ao ethos cortesão enquanto renúncia ao século. O cavaleiro 
cristão (Miles Christi) não mais deve partir em demanda por aventuras que redundassem em fama, prestígio ou reconhecimento de suas habilidades e façanhas de armas (prouesse) e cultivar o jogo palaciano do amor cortês, atentatório da disciplina clerical para o sacramento do Matrimônio e intensificador dos laços feudovassálicos.

Ao contrário, a aventura deveria converter-se, à imagem de uma conversio morum beneditina, em peregrinação por Cristo e exaltação de sua glória, em direto detrimento da fama do cavaleiro. O êxito na demanda não mais seria marcado pelas riquezas e fama, mas pela vitória do próprio Cristo - e da Esposa do Cordeiro, seu Corpus Mysticum que é a Igreja - sobre os infiéis, os hereges no seio do Cristianismo e, por certo, também sobre o outro Universalismo Cristológico oponente da Reforma Pontifical, vale asseverar, o Sacro Império Romano. A cavalaria cristã (Militia Christi) é idealizada, no projeto de Teocracia Papal, como o lugar social da prática do amor de Deus. Enquanto expressão da Cidade de Deus na Terra, a Igreja Cristã tem, na cavalaria, sua expressão militar - militante - de expansão universal e retórico-catequética pelas armas.

O amor a ser acalentado pela Militia Christi é, na célebre fórmula de Santo Agostinho, o Amor Dei ad contemptum suum, radicalmente oposto ao ethos da cavalaria cortesã. A expressão - amor de Deus até o desprezo por si próprio - caracteriza a Jerusalém Celestial, a Cidade de Deus em sentido espiritual, anima da Jerusalém Terrestre. Seu ethos pretende, precisamente, efetivar uma conversio morum quanto ao amor próprio à Cidade dos Homens, a Babilônia decaída em pecado. Nesta senda, o ethos cavaleiresco a ser convertido é aquele característico da Militia Saeculi. O amor cultivado por seu ethos - a prática retórico-pedagógica do amor cortês - corresponde à outra conhecida locução agostiniana, o Amor sui ad contemptum Dei, o amor por si mesmo até o desprezo por Deus (BACCEGA, 2015: p. 140).

Com efeito, a sociabilidade desta parentela espiritual que é a cavalaria, em sua vertente mundana, desenrola-se com o ritual do amor cortês. Este fin'amor precipita o enamorado em uma desventura amorosa, em tudo antagônica ao Amor de Deus, sobretudo se recuperada a prédica de Santo Agostinho no Livro X, 22, das Confissões: beata vita est gaudere de Te, ad Te, propter Te ("a vida feliz é fruir de Ti, em direção a Ti e por causa de Ti”, referindo-se a Deus). O vínculo amoroso mundano conduz o herói à prática de proezas e a jurar ilimitada obediência às ordens de sua dama idealizada (BACCEGA, 2015: p.140).

Em virtude das convenções do amor cortês, o juvenis miles, o jovem cavaleiro ou vassalo enamorado, deve amar ardentemente, com grande desejo, ainda que o mesmo conheça uma necessária sublimação. Para Georges Duby, trata-se da encenação de um idílio mundano aparente, um jogo estetizado para uma compensação simbólica pela condição, na prática, forçadamente celibatária da pequena nobreza de cavaleiros errantes, até que conseguissem se casar com uma dama com grande dote. O jogo do amor cortês parece exigir a superação de um interdito fulcral quanto ao suserano: traí-lo em felonia e instigar ao adultério sua esposa. Todavia, a dama é inalcançável, e enaltecida justamente por sua recusa em favorecer o vassalo amoroso. $\mathrm{O}$ esposo, suposta vítima em potencial do adultério e da ruptura do contrato feudal, não apenas sabe do jogo érotico-disciplinar, como o permite e mesmo fomenta (DUBY, 2001: pp. 59-63). 
Como assinala Duby, essa forma aristocrática do amor cortês também foi aclamada por trovadores como vraie amour ou fine amour, uma forma perfeita e acabada de amor, "depurado como o ouro mais fino" (DUBY, 1981: pp. 230-233), essencialmente distinta, portanto, do amor vulgar e promíscuo dos camponeses. O fin'amor, como designado por André, o Capelão, no Tractatus de Amore de 1184, composto na corte de Felipe Augusto (1180-1223), de fato corresponde a um torneio que visa a um guerredon (literalmente, "convalescença"), uma recompensa, identificada com a esposa do suserano. Na melhor das hipóteses, o enamorado consegue atrair uma reverência amedrontada da dama e uma condescendência tácita do esposo, certo de que o guerredon não será o adultério. No que concerne à relação feudovassálica, o amor cortês pressupõe um embate desigual, pois o vassalo será derrotado, em um quadro social em que o maior pecado seria o adultério da esposa do suserano. Sua função é recusar as investidas do enamorado vassalo (DUBY, 2001: pp 24-26).

O lugar da memória (Pierre Nora), por excelência, das representações e mesmo das práticas retórico-disciplinares do amor cortês foi, sem dúvida, a Lírica Trovadoresca. A compreensão dos grandes cantos de amor dos trouvères ou do canso dos poetas occitânicos, os troubadours, depende de se observar o preceito de Jean Frappier, quanto a distinguir o fine amor da cortesia em sentido estrito. A última corresponde ao ideal do comportamento aristocrático, uma forma de savoir-vivre que envolve polidez, elegância, hábitos refinados, e algo para além das qualidades unicamente sociais: a honra cavaleiresca. O amor cortês instaura-se neste ambiente, estatuindo, ao fim de diversas etapas, uma verdadeira ars amatoria. Na poesia trovadoresca, o amor cortês figura virtualmente como uma relação adúltera, já que a dama é habitualmente casada, destinatária de um cortejo amoroso, de uma súplica sentimental veiculada por poemas (RÉGNIER-BOHLER, 2002: pp. 48-49).

A propósito do amor cortês, estão de acordo historiadores de diversas orientações teórico-metodológicas, tais como Jean Flori, Dominique Barthélemy e o próprio Duby, afirmando que é essencial, para a compreensão dessa mimese disciplinada das relações e desejos eróticos, a contemplação do fundamento feudal. Por isso, o vocativo frequente nos poemas é "minha Senhora" ( $m i$ Dona, em occitânico, mia Senhor, em português), posto que o eu-lírico se encontre ao dispor da dama como um vassalo ante seu suserano, devendo-lhe, inclusive, homenagem. Conquanto não se especifique o ritual feudal nas cantigas trovadorescas, está latente a saisine, a posse pelo ósculo, como a se tomar posse de um feudo (RÉGNIER-BOHLER, 2002: p. 49).

A posição amorosa deve sempre estar vinculada ao valor pessoal daquele que aspira a cortejar uma dama, devendo o miles mostrar-se leal e cortês, dedicar toda a atenção ao elogio da amada, à espera do guerredon. Nas regiões ao norte da atual França (langue d'oül), esta ars amatoria da nobreza feudal inserir-se na problemática bem romanesca do aperfeiçoamento pessoal por meio da ostentação das virtudes bélicas nos torneios e combates. Tratando-se, como se argumentou, de uma disciplina do desejo e de uma sublimação idealizada da sexualidade, paradoxalmente elevada a um dos valores fundamentais da aristocracia guerreira, o jogo do amor cortês apresenta um conteúdo civilizatório. Afinal, o fin'amor permite a pacificação das condutas nas cortes principescas e senhoriais, sublimando o potencial desagregador e subversivo da felonia e do adultério. No "Outono da Idade Média" (Johann Huizinga), percebe-se uma consequência civilizatória notável da prática reiterada e combinada do amor cortês, das 
justas e torneios, que, simulando e regulando a guerra, também contribuem para o processo de curialização da nobreza de espada.

Combater por Cristo e Seu Corpus Mysticum, a Igreja, como desejava o projeto de poder cristológico e universal da Reforma Pontifical (dita "Gregoriana"), ou, ao inverso, sedimentar o sinalagma feudal com a liturgia palaciana do amor cortês e seu ethos guerreiro, como ambicionam as chancelarias régias, principescas e imperial? Ser Militia Saeculi a serviço do Regnum (Sacro Império Romano) ou Militia Christi em prol do Sacerdotium (Igreja que aspira à uma Teocracia Pontifical)? No fundo, qual projeto universalista cristológico deve ser assumido? Qual o lugar-tenente legítimo de Jesus Cristo na Terra, caput da Igreja como instituição total que congrega toda a Cristandade: o Papa ou o Imperador? Qual Imperdor dos Romanos: o latino ou aquele que governa o "país dos gregos"? Tal é a disputatio retórico-política que subjaz às narrativas arturianas e graalescas. Em síntese, o bom combate paulino pela Plenitudo Potestatis no tempo do Milênio.

\section{CONSIDERAÇÕES FINAIS: uma nova demanda pelo Santo Graal.}

No mito artúrico-graalesco, o narrema-semantema Galaad-Graal consiste em uma espécie de locus retórico-político de compromisso entre a nobreza feudal do ethos do amor cortês e a aristocracia clerical da Reforma Papal e sua Vita vere Apostolica. Galaad é o lugar mito-poético da constituição de uma concertação ou coalizão política não isenta de tensões e controvérsias - no seio do bloco histórico hegemônico nas formações sociais centro-medievais, composto pelas duas aristocracias, a clerical e a laica. Deste modo, Galaad-Graal repristina, ou seja, retorna ao evento primordial do mito illo tempore, seu antitypus retórico-alegorético, como nos é descrito no Capítulo 31,48 do Livro de Gênesis. É sobre o Monte Galaad que o patriarca bíblico Isaac pactua a paz com seu tio Labão, que ele havia lesado e com cujas filhas Raquel e Lia entreteve relações carnais. O Monte Galaad, ademais, é bendito e consagrado nos Salmos 60 e 107 como posse direta de Deus, penhor da Primeira Aliança, entre Iahweh e o povo judeu.

Se pudermos concluir - e tal não nos parece despropositado - que a Ordem dos Templários foi ideologicamente projetada para ser a Nova Militia Christi, tão enaltecida por São Bernardo de Claraval, avalizada por Eugênio III, então não será dificultoso identificar nos Templários os Templeisen, aludidos no Parzifal (c.1220) do Epiker alemão Wolfram von Eschenbach (c.1170-c.1220), o que pode acenar para uma explicação plausível para a caracterização do sergente de Jesus Cristo, Galaad, como um cavaleiro branco com o emblema da cruz vermelha. ${ }^{4}$

Por sua vez, o narrema-semantema Galaad-Graal revela-se como apoteose da Militia Christi e, ao mesmo tempo, temor e danação para a Militia Saeculi. Como discorremos, os Templários consignam, ao nível mito-poético, a clericalização de uma cavalaria cristã, correspondendo a uma concreção da Igreja em armas, por meio do desempenho de seu officium de monges-guerreiros. 
E quanto à Militia Saeculi? As pesquisas da historiadora franco-russa Zoé Oldenbourg, que originaram o livro $O$ massacre de Montségur (The massacre at Montségur, 1959), coletam indícios de oralidade segundo os quais, durante o cerco à última grande fortaleza cátara, o castelo de Montségur (edifício situado na região occitana de Ariège, ao sopé dos Pirineus), em uma das batalhas, os cavaleiros católicos teriam recuado diante de um cavaleiro de armadura branca, que os sitiantes identificaram ao "Cavaleiro do Graal", que se insinuava entre as ameias. Interessa aqui constatar que os cátaros, autorrepresentados como a verdadeira Igreja de Deus, também projetam no mitemas do Santo Graal o penhor de Deus, que os protegeu dos cavaleiros do Demiurgo, a divindade má que criou o mundo material.

Neste contexto, pensamos que o Santo Graal e sua implícita teologia cristológica da Graça apontam para o que Georges Duby define como traço de mentalidade, uma figura do imaginário que constitui um denominador comum a uma determinada sociedade (BASTOS, 2010: pp. 217-220). Nas célebres palavras de Jacques Le Goff, “o que há de comum entre César e um legionário romano" ou "entre Colombo e seu grumete". Se o Santo Graal simboliza a Graça para o braço armado idealizado pela Reforma Papal, caso dos Templários, e para aquela que foi, talvez, a mais perigosa, organizada e desafiadora das heresias, os Cátaros, o que devemos inferir? Se Muntsalvatsch, o Castelo do Graal, pode tanto estar no Templo de Salomão e suas mais de 100 comendadorias, quanto ser encarnado em Montségur, o que é, em profundidade, o Mistério Eucarístico do Santo Vaso? O Graal é um poderoso instrumento retóricopolítico que, no fundo, corresponde a uma teia complexa de relações e tensões sociais metaforizadas no Cálice Crístico. Estamos aqui diante de uma estrutura mental de longa duração, desde a discreta figura no Evangelho Apócrifo do Pseudo-Nicodemos, datado de meados do século IV, até suas múltiplas identidades centro-medievais. São figurações do Graal a travessa ou prato para iguarias, gradalis, na corte do Rei Pescador em Perceval ou Le conte dou Graal, atribuído à auctoritas de Chrétien de Troyes, a pedra verde, lapsit exiliis, caída da coroa de Lúcifer durante a revolta dos anjos maus, no Parzifal alemão, ou o célebre Cálice da Santa Ceia, nos ciclos de prosificação da Matéria da Bretanha na primeira metade do século XIII.

Portanto, há uma maneira, que nos parece legítima, de resgatar o Santo Graal dos circuitos alienados de reprodução simbólica deste Dasein inanimado que é o Capital. Vislumbrar e entender o Santo Graal como eloquente metonímia de uma totalidade em movimento, de um fluxo dialético entre práticas (modo de produzir, Produktionsweise) e representações (modo de representar, Vorstellungsweise), tecendo o compasso da sinfonia histórica centro-medieval.

\section{REFERÊNCIAS BIBLIOGRÁFICAS}

BACCEGA, Marcus. O Sacramento do Santo Graal. Decifrando o imaginário medieval. Curitiba: Prismas, 2015.

"Literatura Medieval e Guerra Retórica: em torno do roman medieval”. In. ZIERER, Adriana. BOMFIM, Ana Lívia Vieira (Org.). História 
Antiga e Medieval. Conflitos Sociais: guerras e relações de gênero: representações e violência. São Luís do Maranhão: Editora UEMA, 2017, v. 6, p. 347-356.

. "O fetiche do Capital e a clausura do imaginário". In: VVAA. Escritas. Goiânia: Editora Kelps, 2008.

. "Apoteose da Cavalaria Cristã: Ignácio de Loyola e a Retórica Medieval". In. MAGALHÃES, Ana Paula Tavares (org.). Linguagem e Produção do Discurso na História: fontes, modelos e problemas da Cristandade Latina (VXVI). São Paulo: Humanitas, 2015.

BARBER, Richard. The Holy Grail. Imagination and Belief. Cambridge: Harvard University Press, 2005.

BASTOS, Mário Jorge da Motta. "Georges Duby: um ogro historiador em busca da totalidade”. In. ZIERER, Adriana. Uma viagem pela Idade Média. São Luís do Maranhão: Editora UEMA, 2010, p. 217-230.

DUBY, Georges. Idade Média, Idade dos Homens. São Paulo: Companhia das Letras, 2001.

Le Chevalier, la Femme, le Prêtre. Paris: Hachette Littératures, 1981.

FIORIN, José Luiz. Figuras de Retórica. São Paulo: Editora Contexto, 2014.

FRANCO JR, Hilário. "O fogo de Prometeu e o escudo de Perseu: reflexões sobre imaginário e mentalidade". In. Idem. Os três dedos de Adão. Ensaios de Mitologia Medieval. São Paulo: Companhia das Letras, 2010, p. 49-91.

GINZBURG, Carlo. Relações de Força. História, Retórica, Prova. São Paulo: Companhia das Letras, 2008.

Mitos, Emblemas, Sinais. Morfologia e História. São Paulo: Companhia das Letras, 2003.

MARX, Karl. Das Kapital. Kritik der politischen Ökonomie. V. I. Paderborn: Voltmedia, 2007.

MEGALE, Heitor. A Demanda do Santo Graal. Das origens ao códice português. Cotia: Ateliê Editorial, 2002.

MONGELLI, Lênia Márcia. FRATESCHI, Yara (org.). Estética Medieval. Cotia: Íbis, 2003.

MOURA, Maria Tereza Rocha de Assis. A Prova por Indícios no Processo Penal. Rio de Janeiro: Editora Lumen Juris, 2009.

OLDENBOURG, Zoé. The massacre at Montségur. A History of the Albigensian Cruzade. London: Weidenfeld \& Nicolson, 2001.

PÉCORA, Alcir. Máquina de Gêneros. Novamente descoberta e aplicada a Castiglione, Della Casa, Nóbrega, Camões, Vieira, La Rochefoucauld, Gonzaga, Silva Alvarenga e Bocage. São Paulo: EDUSP, 2001.

PERNOUD, Régine. Os Templários. Lisboa: Publicações Europa-América, 1974.

RALLS, Karen. The Templars and the Grail. Knights of the Quest. Wheaton: First Quest Edition, 2003. 
RÉGNIER-BOHLER. “Amor cortesão". In. LE GOFF, Jacques. SCHMITT, JeanClaude. Dicionário Temático do Ocidente Medieval. São Paulo: Companhia das Letras, 2002.

SILVA, Pedro. História e Mistérios dos Templários. Rio de Janeiro: Ediouro, 2001.

\footnotetext{
${ }^{1}$ Para maiores detalhes e exemplos em particular, remetemos o leitor a nosso O Sacramento do Santo Graal (2015), publicado pela Editora Prismas.

${ }^{2}$ Novamente remetemos o leitor interessado em um desenvolvimento mais profundo desta argumentação a nosso O Sacramento do Santo Graal (2015).

${ }^{3}$ A saber, as cinco partes da Retórica Clássica, de Tísias e Córax, passando por Aristóteles, Cícero e Quintiliano, recepcionada pela cultura de alto repertório medieval por meio da Rhetorica ad Herennium, do Pseudo-Cícero (c. 90 d.C.) são: inventio, dispositivo, elocutio, memoria e pronuntiatio.

${ }^{4}$ Neste ponto, permitimo-nos discordar do eminente historiador e erudito arturiano inglês Richard Barber, em seu instigante The Holy Grail: imagination and belief (2004). Barber afirma que o nome "Templeisen" ou "Templiesen" foi simplesmente inventado por Wolfram von Eschenbach, não tendo qualquer relação com a Ordem dos Templários. O medievalista inglês procura justificar sua visão a partir da evidência de que os primórdios da organização mais sistemática da Ordem do Templo no Sacro Império Romano datariam apenas de 1227. Com efeito, há um primeiro mestre regional alemão apenas em 1241, conhecido pelo título de Gebhard Praeceptor domorum milicie Templi per Germaniam, tendo permanecido neste posto até 1244. Entretanto, a reputação e a expansão da Ordem dos Templários pela Europa, iniciada com a concessão papal de reter doações e tesouros para obras cruzadas, advinda da bula Omne datum optimum (1139), promulgada por Inocêncio II (1130-1143) certamente penetrou os domínios imperiais, haja vista a extensão territorial eurasiana das casas (comendadorias), castelos e mosteiros beneditinos vinculados à Ordem, sua dileção, inicialmente, por parte da Cúria Papal e o temor que inspirava às monarquias feudais que já despontavam, ainda que timidamente.
} 